\title{
Social Change, Spatial Articulation in the Dynamics of Boomtown Construction and Development (Case Satudy of Metro Tanjung Bunga Boomtown, Makassar)
}

\author{
Batara Surya $^{1}$ \\ ${ }^{1}$ University 45 of Makassar Indonesia, Indonesia \\ Correspondence: Batara Surya, University 45 of Makassar Indonesia, Indonesia. E-mail: \\ batara_surya1945@yahoo.co.id
}

Received: March 15, 2014

Accepted: April 2, $2014 \quad$ Online Published: July 29, 2014

doi:10.5539/mas.v8n4p238

URL: http://dx.doi.org/10.5539/mas.v8n4p238

\begin{abstract}
Lightning-fast physical and spatial changes of urban area stimulates modernization and accelerated construction in Metro Tanjung Bunga district. Physical-spatial change is preceded by the developed functions of new economic activities that emerge the entrance of migrants by infiltrative or expansive. Change of simple social formation into multiple social formation with precapitalist social formation and capitalist social formation therein affects local community marginalization. Working differentiation encourages social interaction process between local community and migrant which engenders social change in local community. Consequences of social change in local community are stratification system from simple stratification into stratification acuity and cultural change from traditional agrarian into industrial urban culture.
\end{abstract}

Keywords: social change, spatial articulation, mode of production, capitalist space, non-capitalist space

\section{Introduction}

Urban development will always work in line with the residential dynamics. Studies on urban development, especially for big cities in Indonesia, are inseparable matters of globalization and modernization impact. Globalization obviously affects the changes of spatial structure and spatial pattern in urban areas.

Dynamics of big cities development in Indonesia in relation with urban development are indicated as inseparable components of economic globalization impact. Fundamental principles of economic globalization are giving emphasis to free trade and economic efficiency. These principles are based on the concept of comparative advantage as correlated positively to the capability to create scale retrenchment in purpose to improve the economic productivity of urban areas. Occurred retrenchment of scale is not only to minimize the unit cost of urban space reproduction outcomes but also to boost economic growth. Mills (1979) states that "in purpose to support economic growth in developing country, it is crucial to function the urban areas efficiently and productively". In developing countries, roles and functions of intercity transportations and those which operate out of the city are uncertain and grow very slowly. It engenders time-, cost- and energy-consuming activities of urban reproduction which at last, they will obstruct its economic growth.

Rapid development on technology and transportation system in developed countries contributes positively to the decrease of proximity (closeness). Moreover, developing industries as well as the existing residential areas expand to the outside of urban areas. It can be identified that those big cities experience an unavoidable size depreciation (Coleman, 1979).

Cities in developing countries including Indonesia have similar problems in their growth process, especially in the development of strategic and economic areas which are generally operated by capitalist sectors in spatial reproduction possession. It means that spatiality is considered as commodity for the needs of production and consumption process. Thereby, if capitalist sectors improve urban area spaces into new economic growth centers, they tend to ignore the space existence of non-capitalist and precapitalist sectors. Current capitalism penetration and invasion to economic development spatially by utilizing urban spaces have not dominated or abolished spaces of non-capitalist sector yet. It has been a characteristic of big cities in Indonesia especially in central business district with complex land use patterns, that live poor townsmen working at informal sector therein. The needs of urgent proximity (distance closeness) to industrial districts, trade centers and harbor areas indicate that 
in surrounding areas of central business district there will be an increasing number of poor settlement (slums area) and urban marginal communities that lack of capacity and skill. As the consequence, they won't be involved in formal sector activities of the city which are powered by capitalist and municipal bureaucracy. They will work only in informal sectors and be a resident of town. At last, they will utilize economic activities of the town centers for their "informal" business activities. Similar phenomenon occurs when capitalist sector penetrates and commits a spatial invasion to local community in suburban areas.

This process is also experienced by Makassar city in its development to be a "Metropolitan City". It experiences an inseparable effect of globalization impact and capitalism in the name of urban modernization. Ongoing globalization creates the occurrence of social, economic, cultural and demographic process to urban areas in Makassar city. Indeed, this phenomenon also occurs in suburb areas of Metro Tanjung Bunga, Makassar. This process is indicated by the existence of intensive land conversion which brings saturation point to the central business district. Furthermore, this condition leads to deconcentration process of new economic and social activities in suburb areas of Metro Tanjung Bunga, Makassar. Attainment of this saturation point is also caused by status change of Makassar as well as the surrounding areas that become Mamminasata Metropolitan City. Some of them is also boosted by dynamics of economic production in Makassar as the core-city and buffer zone of surrounding areas (Maros, Takalar and Sungguminasa).

Development of Metro Tanjung Bunga district have influenced revolutionary on physical and spatial change and it significantly affects social-economic condition of local community. It can be seen from the shift of social structure, social process, social system and cultural pattern of local community. Occurred shift of social structure is indicated by weakened access of community to achieve economic opportunity caused by the change of traditional work system into industrial work system. Rapid construction of Metro Tanjung Bunga district up to now becomes a determinant of social change process within the local community as indicated by the change of modes of production that were boosted by technology and transportation system development. This domination on spatial possession and mode of production by capitalist indicate ongoing process process of change in the social system, patterns of social relationship, social interaction and cultural patterns in local community of Metro Tanjung Bunga district.

\section{Research Method}

This study is conducted in boomtown area of Metro Tanjung Bunga, Makassar city. It uses case study approach because of some reason that: (a) physical-spatial changes in Metro Tanjung Bunga district are specific and revolutionary which are complexly arranged. (b) it's case has an obtrusive nature. (c) it has a complex case context. (d) nature of this case aims to understand one background or phenomenon of social formation change in local community as determined by physical and spatial changes.

This type of study uses "dominant-less dominant design" approach as referred to Creswell (1994). It uses qualitative approach as the dominant and quantitative one as the supporting approach which the later is used for certain thing.

\section{Discussion}

\subsection{Articulation of Production Mode}

Theory on articulation of production mode refers to thoughts of Karl Marx and Frederic Engels on precapitalist mode of production or capitalist mode of production. Indeed, articulation of production mode is a concept inspired and practiced by people in construction problem areas and political tenacity for communities in the Third World instead of advanced industrial communities; it belongs to the notion of central object in Marx analysis.

One of the most important theoretical problems that become the target of articulation of production mode theory is characterization of social formation representing combination of different modes of production. Specifically, there is one dominant mode of production in an articulation with the other modes of production or production relations which are different in the scope of social formation in urban community.

Social formation is comprehended as a concrete totality which is institutionalized economically, politically and ideologically in certain geography and in certain period of time. Social formation can be defined as a combination that determine or make it as superposition of various "pure" modes of production, and this mode of production is the dominant among others. Every mode of production is characterized by role as assumed by one mode or the others in three levels; economy, politics and ideology. Yet, the most determinant role is the economic level. It is a level which is explicitly characterized by dominant position in co-existence process.

Pierre-Phillipe Rey analyzes social formation as a combination of modes of production through observations on 
transition process from feudalism to capitalism in term of combination differences and forms of mode of production. One of his findings is that stable social formation in the Third World up to now occurs between capitalist mode of production and capitalist mode of production or non-precapitalist mode of production as the consequence of capitalism development in the Third World (Rey, 1975).

Taylor also contributes to the theory improvement on articulation of production mode. Early 1980's, Taylor had improved theory on articulation of production mode. He refuses backwardness concept and substitutes it with 'limited and uneven development'. Taylor also substitutes term of 'shift of social formation' to 'social formation dominated by articulation of at least two modes of production that is capitalist modes of production and non-capitalist mode of production where capitalist becomes more dominant or will more dominant than the others (Taylor, 1979).

Lately, articulation of production mode approach have been used to explain the broader concrete studies including imperialism research, petty commodity production, residents mobility and unstable spatial articulation in context of Metro Tanjung Bunga district construction as the newborn city. Obviously, it experiences revolutionary of physical-spatial changes as powered by the existing capitalism and land possession that create change of social system, social structure and cultural patterns of local community. Domination on land and spatial possession by capitalist sector for commercial activities development and modern settlement construction directly affects marginalization and incapability of local community to access spatial reproduction whether in physically and economically. This condition is indicated by the change of social system of local community from homogeneous to heterogeneous social system, thus it affects social system, social structure and cultural patterns of local community.

Based on theoretical assumption about articulation of mode of production related to construction dynamics and Metro Tanjung Bunga boomtown, Makassar, it shows that spatial articulation in the context of boomtown development in this district is followed by change of social formation of local community which occurs in two categories; infiltration and expansion. Articulation of mode of production expands to newer social formation that occurs in local community which is significantly affected by penetration and invasion of capitalism. Direct implication is the changes of spatial structure and spatial patterns in Metro Tanjung Bunga district, Makassar. Furthermore, it develops to quite complex spatial pattern and domination of spatial possession by capitalism as the characters of development dynamics in suburb areas on Metro Tanjung Bunga district.

Table 1. Comparison on spatial utilization of Metro Tanjung Bunga district in 1994-1996 and 1997-2010

\begin{tabular}{lllllll}
\hline No & Land Utilization & $\begin{array}{l}\text { Land area in } \\
\mathbf{1 9 9 4 - 1 9 9 6}(\mathbf{H a})\end{array}$ & $\mathbf{\%}$ & $\begin{array}{l}\text { Land area in } \\
\mathbf{1 9 9 7 - 2 0 1 0}(\mathbf{H a})\end{array}$ & $\mathbf{\%}$ & Information \\
\hline $\mathbf{1}$ & $\mathbf{2}$ & $\mathbf{3}$ & 4 & $\mathbf{5}$ & $\mathbf{6}$ & $\mathbf{7}$ \\
1 & Rice field & 889.14 & 74.5 & 27.42 & 2.29 & Decrease \\
2 & Pond & 108.40 & 9.04 & 15 & 1.25 & Decrease \\
3 & Mixed farm & 11.20 & 0.94 & 5 & 0.42 & Decrease \\
4 & Settlement areas & 19.35 & 1.62 & 101.39 & 8.46 & Increase \\
5 & Unoccupied land & 160 & 13.36 & 85.32 & 7.12 & Decrease \\
6 & Economic and social facilities & 5.75 & 0.48 & 17.00 & 1.42 & Increase \\
7 & Recreation & 4 & 0.33 & 18.32 & 1.53 & Increase \\
8 & Developed Land Preparation & - & - & 519.76 & 43.39 & New \\
& by GMTD public limited & & & & & Development \\
& company & & & & & \\
\hline
\end{tabular}

Source: Monographic Data Result of Tanjung Merdeka Village.

\subsection{Social Formation and Spatial Change of Metro Tanjung Bunga District, Makassar}

Metro Tanjung Bunga district is one of boomtown areas located in suburb area of Makassar city which is recently under development and construction phases. Revolutionary physical-spatial changes of Metro Tanjung Bunga district are occurred because of two major factors, centrifugal factor and centripetal factor (functions of urban spaces spatially). These two factors trigger an expansion of strategic and economic space functions in Makassar as indicated by modernization in suburb areas of Makassar that reconstructs newer structure and spatial pattern formation in Metro Tanjung Bunga district, Makassar. Emergence of decentralization policy for municipal construction generates accelerated process on Makassar city construction rapidly and revolutionary in 
purpose to develop economic and commercial activities functions of Makassar city.

Conformed facts in the field show that spatially capitalist penetration becomes the major motor of development acceleration in Metro Tanjung Bunga district. The existing capitalism power is preceded by domination on land possession and finally it expands to domination of non-capitalist or precapitalist production factors. This process shows that domination on means of production are shifting to domination on spatial reproduction and later on it creates spaces in representational manner. This reality is in line with the thoughts of Lefebvre (1981) stating that domination on means of production to spatial reproduction will always be followed by spatial creation in representational manner. Spatial creation in representational manner with various physical and spatial forms trigger an entrance of expatriates to Metro Tanjung Bunga district. At last, this process becomes the determinant of new social formation in local community of Metro Tanjung Bunga district.

In the beginning, if the settlements in Metro Tanjung Bunga district that were preceded by the agrarian villager's characters, expatriate mobility emerges different domination process on the means of production between local community and those immigrant. This condition encourages the emergence of two simultaneous and coexisted modes of production types. Conformed facts during the development process in Metro Tanjung Bunga district reconstruct precapitalist mode of production in one side and capitalist mode of production in the other sides. This condition draws an illustration that methods of production are creating co-existence between one method and the others. Social reality is in line with Marx's thoughts where production method or mode of production is an compound concept between force of production consisting of combination of mean of production and relation of production. They covers relation between capital owner and employee which is not only built on production power and formed class structure, but also built on the demand of production efficiency, collection of high profit and even varied conflicting interests between the employee and capital owner.

Other than the mentioned factors above, conformed fact shows that occurred rapid and revolutionary on spatial and physical changes in Metro Tanjung Bunga district generate morphological change of district from rural morphology to various and complex urban morphology. Those various formed morphologies belong to penetration and invasion of capitalism, thus they form "dualistic" municipal district; modern and traditional, urban and rural, well-ordered and bad-ordered, high quality and slummy. This morphology evolves into informal and formal pattern activities. Both of these physical and spatial changes occur in Metro Tanjung Bunga district.

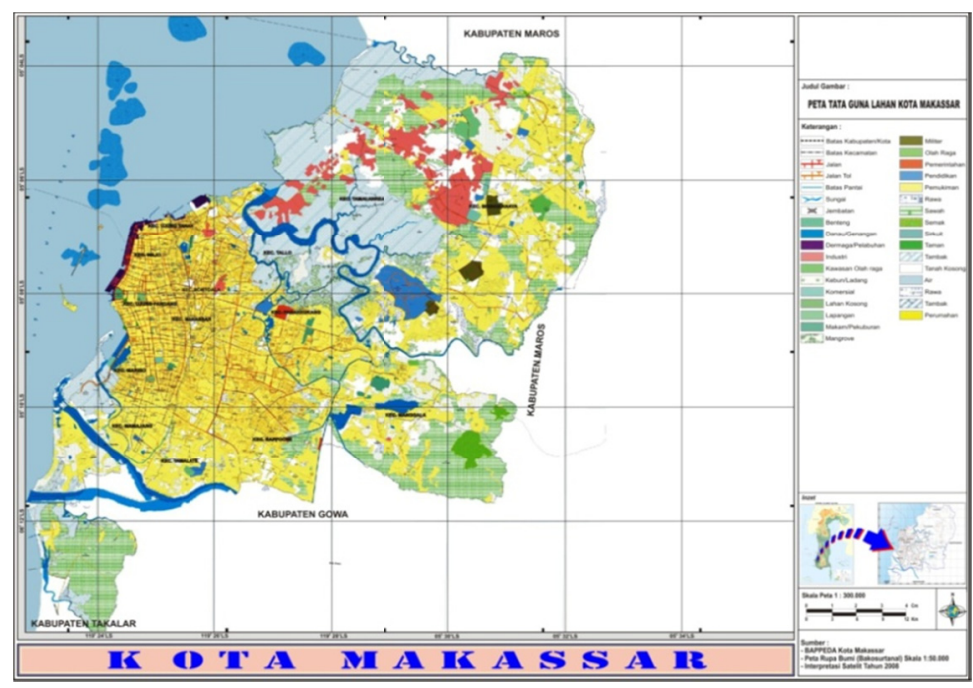

Figure 1. Land utilization in Makassar city

Economic activities with official status as brought by capitalism can be seen by the existence of business enterprise in form of corporation and other family-oriented business enterprises and private enterprises in its official status. Obviously, it subjects to one rule categorized as formal sector. While the other sectors are known as the representative of disadvantaged class that is called as informal sector. Political justification toward the existence of informal sector growing up today in Metro Tanjung Bunga district repositions the existence of these two formed and coexisted types of social formations. Conformed facts show that it is not all of the informal sectors as mode of production of local community becomes an illustration of formal activities, even what is growing up today is its inverse activities. It shows that this process generates the new social formation within 
local community. It creates an illustration that development of two coexisted modes of production (precapitalist and capitalist) in Metro Tanjung Bunga district.

Spatial and physical changes as the determinants of social formation change in Metro Tanjung Bunga district, Makassar relate closely to the existence of capitalism that dominate the means of production into spatial reproduction and spatial formation in representational manner. Spatial formation in representational manner is preceded by penetration of capitalism followed by invasion that is indicated by structural changes of land possession and new functions formation. It also associates positively with technology and transportation progression.

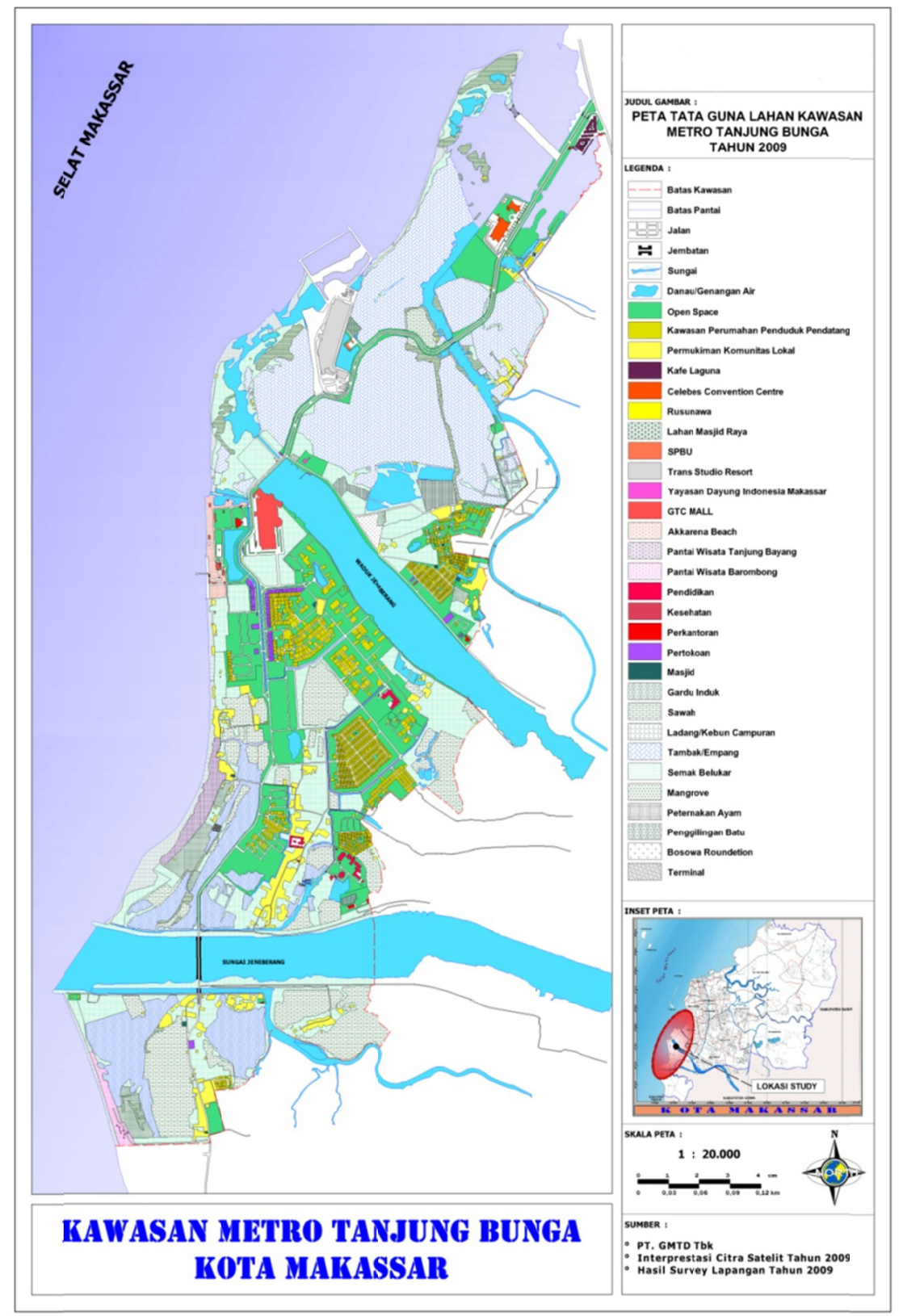

Figure 2. Spatial patterns of Metro Tanjung Bunga District, Makassar

Rapid and revolutionary on physical-spatial changes directly trigger the occurrence of modernization and change of mode of production in local community as the total impacts of capitalism influence. Furthermore, the change of production mode of local community expands to fragmentation on livelihood reorientation in local community 
(formal and informal, agrarian and non-agrarian). It creates the occurrence of precapitalist production method in one side and capitalist production method in the other sides. Domination on capitalism production method triggers separation of local community's settlement location in spatial manner in Metro Tanjung Bunga district. It brings significant influence to social formation changes of local community.

On going social formation changes of local community show the differential stratification, status and employees' class which are homogeneous in the beginning. It shifts them into heterogeneous community and changes their work relation pattern to urban and industrial as brought by capitalism with its complex character. Complexity shows the difference of individual adaptive capability of local community to response environmental changes. Direct impact of this condition is the change of social system of local community. Finally, it creates incapability of local community to access spatial reproduction resources which effects local community marginalization in Metro Tanjung Bunga district, Makassar.

Spatial-physical changes engineering in Metro Tanjung Bunga district encourages new social formation which coexists from precapitalist mode of production and capitalist mode of production. On the contrary, social formation as indicated by these coexisted mode of production is also determined by the change of spatial structure as characterized by the occurrence of coexistence between "capitalist" spaces and "non-capitalist" ones. Phenomenon on urban spatiality as determined or reflected by dynamics of social formation based on these capitalist and non-capitalist articulation of production mode as introduced in this study is called as a phenomenon of 'articulation of Urban Spatiality'.

\subsection{Concept of Articulation of Urban Spatiality}

In purpose of this study, in the first phase, there will be an explanation on differences between"phenomenon" of articulation of urban spatiality and "concept" of articulation of urban spatiality. Phenomenon on articulation of urban spatiality refers to occurred articulation in cities of the Third World. When spatial capitalism sector penetrates to social spaces of local community, they experience articulation physically and socially. In social side, occurred articulation in social formation shows powers of at least two coexisted modes of production, especially capitalist mode of production and non-capitalist or precapitalist mode of production. While in physical side, it shows at least two types of spatial land possession as 'capitalist space' and 'non-capitalist space'.

Concept of articulation of urban spatiality is a planning concept of urban spatiality by considering change of social formation in certain urban district, especially if the plan is dominated by construction interests by capitalist sector.

Essentially, concept of articulation of urban spatiality suggests spatial planning that considers interests of the various parties in social formation. This concept does not impose any integration and repression forms as applied for dominant parties interest from social formation to the end of plan implementation. Concept of articulation of urban spatiality in this context requires the planner to consider and to monitor the changes of social formation continuously. If predicted result shows that upcoming social formation appears in some phases, these plan implementation phases should be adjusted with the phases of social formation changes too.

\subsection{Sustainable Urban Development and It's Problems}

In general, concept of sustainable urban development is defined as urban development which is setting out economic, social, cultural and environmental aspects in balance. This balance is important to ensure that sustainability still works for the existing natural resources without alleviating opportunity for the future generations to get its benefit. It is appropriate with compromised definition in Conference Strategies for Sustainable Cities (1999): "economy, ecology and social cohesion are the pillars of a sustainable city. These must be in balance and therefore require an integrated approach....". Therefore, some keywords on sustainable urban development are economy, natural resources and social cohesion developed in balance and cohesiveness (Widianto, 2010).

\subsection{Implement the Concept of Articulation of Urban Spatiality}

By understanding sustainable urban development above, implementation of the concept of articulation of urban spatiality should be considered to those three pillars - economy, ecology and social cohesion. In this context, economy relates to urban efficiency; ecology relates to an effort to prevent the utilization of Open Green Space from other necessities including squatters activity; while social cohesion relates to an effort to prevent social conflict, as the impact of imbalance urban land possession, for example.

Based on economic aspect, implementation of articulation of production mode relates to urban efficiency which is an inseparable element of economic globalization. Fundamental principle of economic globalization is emphasizing to free trade and economic efficiency. These principles are based on concept of comparative 
advantage stating that an economic activity is produced in a place that relatively more efficient than the others (Adiningsih, 2005). In urban area, the importance of efficiency relates to capability of the city to create retrenchment of scale (Eisenring, 2006). Every service and production activity subjects to retrenchment of scale. Under similar input prices, large producer will get lower unit cost than the small one (Mills, 1979). In urban scope, retrenchment of scale means time and energy efficiency to produce urban goods and services. The more economic of the needed time and energy in producing them, the more efficient of this urban productivity.

In cities of the Third World, most of the residents who work in central place of urban economic activities are the poor class. Disobedience on principles of articulation of urban spatiality in planning strategy forces the poor in urban area, in anyway, to find the closest place with the work location. As the consequence, there will be an excessive sporadic agglomeration in the central place of urban economy. Various efforts have been done to solve this problem, but almost all of them are fail because of incapability of municipal government to solve the major problem, i.e., land supply in urban area to ensure the availability of legal settlement for the majority of the poor (McAuslan, 1986). Concept of articulation of urban spatiality offers spatial planning model by considering the functions of all parties' activities who are exist in social formation to reach urban efficiency.

Based on ecology aspect, concept implementation of articulation of production mode relates to the effort to prevent capital owner agitation in imposing settlement construction within sites which should be protected such as coastal line, marshland and retention basin. Concept of articulation of urban spatiality may also prevent inappropriate utilization toward the existing Open Green Space (OGS), green belt or river basins, such as an impact of squatters activities conducted by subordinated people in social formation as the effect of repressive actions that exists due to disobedience on articulation principles of urban spatiality during urban planning.

In implementing the articulation concept of urban spatiality, the third pillar is creation of social cohesion which is related to the preventive effort of social conflict based on imbalance urban land possession. Based on social perspective, urban development should be followed by enhancement of people's social life quality, especially for those who are generally become subordinate class in urban social formation. In general, conventional way in spatial zoning plan is unable to listen the existence and spatial needs of this marginal class. As the consequence, they are forced to stay in 'remaining' urban areas such as river basins, under the bridge or uncared land. Concept of articulation of urban spatiality offers an approach which is separated from a mere "pro-poor" or simply say, it inclines to the poor. Moreover, it considers the urban poor as people who really exist in urban social formation.

By considering the result of deep researches on formed and upcoming social formation, concept of articulation of urban spatiality offers moderate solution. In one side, urban planning of spatiality still gives spaces for dominant sector (capitalist), and in the other side, it ensures social space possession for those who live in subordinate sector (precapitalist/non-capitalist). Thereby, social cohesion as one of the methods based on three main pillars for sustainable urban development can be maintained and preserved.

\section{Conclusion}

1. Collaboration between government and capital owner in the development of Metro Tanjung Bunga district generates accelerated physical-spatial change through the penetration of capitalism. It causes the shift of means of production into spatial reproduction, encourages an emergence of capitalism on social formation alongside with the precapitalist social formation into multiple social formation. Coexistence of two types of social formation in possession of spatial reproduction dominated by capitalism in social formation causes incapability of local community to access spatial reproduction resources, thus it lays in marginal position.

2. Change from simple social formation into multiple social formation creates the change of social interaction and social adaptation between local community and immigrant.

3. Physical and spatial changes that are followed by change of social formation engenders the change of social interaction and social adaptation. Change of social interaction and adaptation create social change in local community. The consequences of social change internally in local community are stratification acuity from simple stratification to the obvious stratification, status differences from ascribed status into various achieved status corresponds to the conducted efforts relating to skill and competence, change of social system into open social system and cultural change from the values and norms of traditional agrarian into values and norms of industrial life.

\section{References}

Adiningsih, S. (2005). Globalisasi Ekonomi dan Negara Sedang Berkembang, Dalam. Indonesian Journal for Sustainable Future, 1(1), 29-34.

Coleman, J. S. (1979). Can We Revitalize Our Cities? The Urban Predicement. Dialogue, 4(4), 3-13. 
Eisenring, T. S. S. (2006). Efisiensi Perkotaan dan Masalah Penyediaan Tanah Bagi Golongan Miskin Perkotaan. Prospek Edisi, 38, 210-216.

Lefebvre, H. (1981). La Produktion de L'espace. Edition Anthoropos.

Lefebvre, H. (1996). Writing on Cities. Blacwell Publisher.

Marx, K., \& Engels, F. (1976). Manifesto of the Communist Party. Collected Works, 6. Moscow, Progress Publishers.

McAuslan, P. (1986). Tanah Perkotaan dan Perlindungan Rakyat Jelata. Jakarta: Gramedia.

Mills, E. S. (1991). Urban, Efficiency, Productivity, and Economic Development (pp. 121-135). Dalam. Proceedings of The World Bank: Annual Confrence on Development Economic. The World bank.

Rey, P. P. (1975). The Liniage mode of production. Critique of Anthropology, 3, $27-79$.

Surya, B. (2010). Perubahan Sosial Pada Komunitas Lokal Kawasan Tanjung Bunga Kota Makassar, Laporan Hasil Penelitian Disertasi, tidak terpublikasi. Program Pasca Sarjana UNM.

Taylor, J. (1979). Pre-capitalist mode of production. Critique of Anthropology, 6(2), 5-23.

Widiantono, D. J. (2010). Kota Berkelanjutan: Membangun Kota Tanpa Luka. Participatory design. Retrieved from http://buletin.penataanruang.net/upload/data_artikel/Kota.Berkelanjutan. Kota. Tanpa; Luka, diakses 29 Mei 2010.

\section{Copyrights}

Copyright for this article is retained by the author(s), with first publication rights granted to the journal.

This is an open-access article distributed under the terms and conditions of the Creative Commons Attribution license (http://creativecommons.org/licenses/by/3.0/). 